\title{
Sustainability accounting and reporting: an ablative reflexive thematic analysis of climate crisis, conservative or radical reform paradigms
}

\begin{abstract}
Every year the global financial system sends trillions of dollars to finance environmental destruction, but the climate crisis forces change. Notwithstanding vested interests and the unrecognised paradox of adopting environmental business strategies, the implementation of sustainability accounting and reporting (SAR) is imperative to catalyse economic transition away from fossil-fuel and plastic configurations to more sustainable ones. The research proceeded sequentially. First, it scanned the backdrop to the SAR problem and identified key associated institutions and a corpus of recent literature. An initial review to disentangle its conflicting threads generated three themes of 'climate crisis' and 'conservative' or more 'radical' SAR reform paradigms. Iteratively harnessing this thematic lens, the investigation re-examined the SAR literature corpus. It detected fragmented SAR responses to the climate crisis. Accordingly, the research reformulated its first theme to 'dystopic climate crisis fragmentation' but only refined the other two conservative or radical themes to take account of materiality and the split between Anglo-Saxon (IFRS, SSAB) or global and continental institutions (UN, EU, GRI). Conservatives defend incremental standard improvements but retain a single materiality investor-focus. Radicals seek to implement double materiality with a broader spectrum of stakeholders in mind. Both approaches have theoretical as well as pragmatic advantages and disadvantages, so the SAR contention rumbles on. Whilst the standard setting landscape is evolving, division, paradox and contention remain. Given vested interests in the destructive status quo, it would be naïve to expect a harmonious SAR Ithaca to emerge anytime soon. Yet the challenges impel urgent action.
\end{abstract}

\section{Backdrop: Problem, institutions and themes}

\section{SAR problem}

Currently, the private sector and global financial system send 'trillions of dollars towards destruction' (Goldsmith, 2021). The ecological imposts of weak oversight and financial malignancy or shortcomings include excessive carbon emissions, airborne particulates or widespread plastic pollution (Crawford \& Sculthorpe, 2021). More insidiously, commercial intensification and the associated residential or agricultural extension fragments and depletes natural habitats leading to poorly-documented biodiversity loss and eventual species extinction (Jill \& Warren, 2020). Anthropogenic and industrial pressures accelerate emission-intensive property and construction activity, responsible for $38 \%$ of global energy-related $\mathrm{CO}_{2}$ emissions (Hamilton \& Rapf, 2020). Within decades, climate change is projected to dent global GDP by 11-14\% (Guo et al., 2021). Church (2021) recently intimated that, likely, by end of this century, sea levels are likely to rise by $1 \mathrm{~m}$. If all of Greenland's ice sheet melts, they could rise by as much as $7 \mathrm{~m}$. Worryingly, we seem to be drifting towards this latter doomsday scenario, as illustrated by the seemingly inexorable increase in atmospheric $\mathrm{CO}_{2}$ concentration (see Figure 1). Whilst in the 1970s, the annual increase in this GHG was 1 ppm; it now exceeds 2.4 ppm per year.

At the economic level, GDP measurements, devoid of either environmental or social considerations, are depleted performance indicators (Coyle, 2020). The climate crisis, plastic contamination of water sources and air pollution impel urgent accounting systems reforms. At the firm level, one of the fundamental causes of the current environmental crisis is that accounting systems underpinning firm or national 'performance' have, to date, simply ignored responsibilities for the external costs of their activities (Dasgupta, 2021; Laine et al., 2021). The poor disproportionally, bear external costs of industrial and commercial activities and, consequently, suffer their detrimental health impacts as reflected by polarised incidence of chronic disease or mortality. Capitalist denigrators and sceptics vilify its waste, short-termism and self-interested impulses. For these radical idealists, chasing a long-term, collectivist Ithaca, wise government interventions can overcome capitalist limitations to ensure climate justice. Mindful of autocracy, unintended intervention consequences and systems evolution, 
liberals resist collectivist utopian siren calls. This philosophical divide plagues accounting systems reform initiatives, splitting the profession. Free market liberals are conservatives who favour incremental accountancy reforms that protect investor interests. Radicals, on the other hand, favour a triple bottom line approach and want financial documents to integrate economic, social and environmental impacts (ESG).

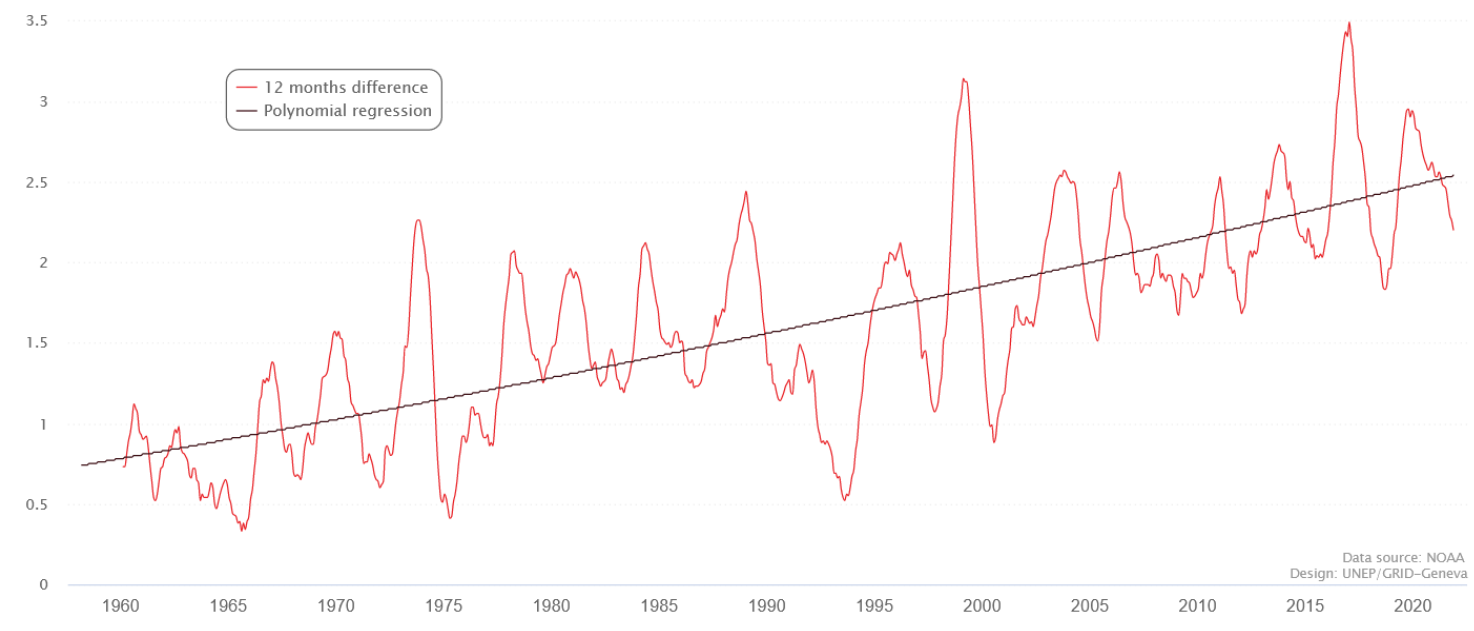

Figure 1: Change in atmospheric carbon dioxide (UNEP, 2021)

Global financial markets call for 'high quality disclosures on climate and other sustainability issues' because sustainability and climate change are the 'defining issue of our time' (Liikanen, 2021, p.1). If integrated with $\underline{S A R}$, the fourth industrial revolution (Industry 4.0), involving real-time data collection, big data analytics, artificial intelligence, and cloud manufacturing could help foster more a resilient, circular economy (Tiwari \& Khan, 2020). Yet to pursue corporate sustainability, organisations need to accept paradox, embrace technology and become strategically agile (Ivory \& Brooks, 2018).

In additions to private commercial sector adjustments, the urgent climate change problem requires a blend of public sector resilience policies, transition infrastructure and SAR reform. Market optimists like R. Cohen (2020), intimate that investors increasingly assess impact as well as risk and return. Eventually, their argument is that free markets will evolve and drive capital towards optimal solutions, especially if prodded by more-eco-friendly accounting frameworks. Market optimists believe that technological and financial evolution will solve the climate and other environmental crises. Keynes was more sceptical of market solutions and considered that, 'the vast majority of those who are concerned with the buying and selling of securities know almost nothing whatever about what they are doing' (Keynes, 1930, VII, pp. 360-61). Yet the climate crisis is urgent and recent evidence suggests there is a gap between climate aspirations and fossil fuel use reality. In fact, fossil fuel production plans intimate that by 2030 the world will consume more than twice the amount of fossil fuels than is consistent with limiting warming to $1.5^{\circ} \mathrm{C}$ (United Nations Environment Programme, 2021). To address this market failure and internalise the carbon externality, UNEP and others favour carbon pricing. The consumer at the petrol pump or paying utility bills will protest. Consumer resistance aside, conceptually $\mathrm{G}$ in ESG is process not outcome. Beyond that, it is unfeasible to measure downstream $\underline{\mathrm{CHG}}$ (scope 3). Instead, Kaplan proposes to use $A B C$ for inventory accounting for upstream supply to allocate emissions to products with possibility of offset for E-liability reporting (Kaplan, 2021).

\section{SAR institutions and issues}

However, the sustainable accounting field is contested, disordered and fragmented. Heterogeneous companies confront multiple competing CSR frameworks with inconsistent sustainability metrics (Feix \& Philippe, 2018). Kaplan (2021) describes the current sustainable accounting scene as an 'alphabet soup' encompassing acronyms like $\underline{E S G}, \underline{C S R}$, etc. Figure1 illustrates some of the institutions in the SAR landscape that divides into market liberals with a conservative view on standards and the opposing radical camps. 


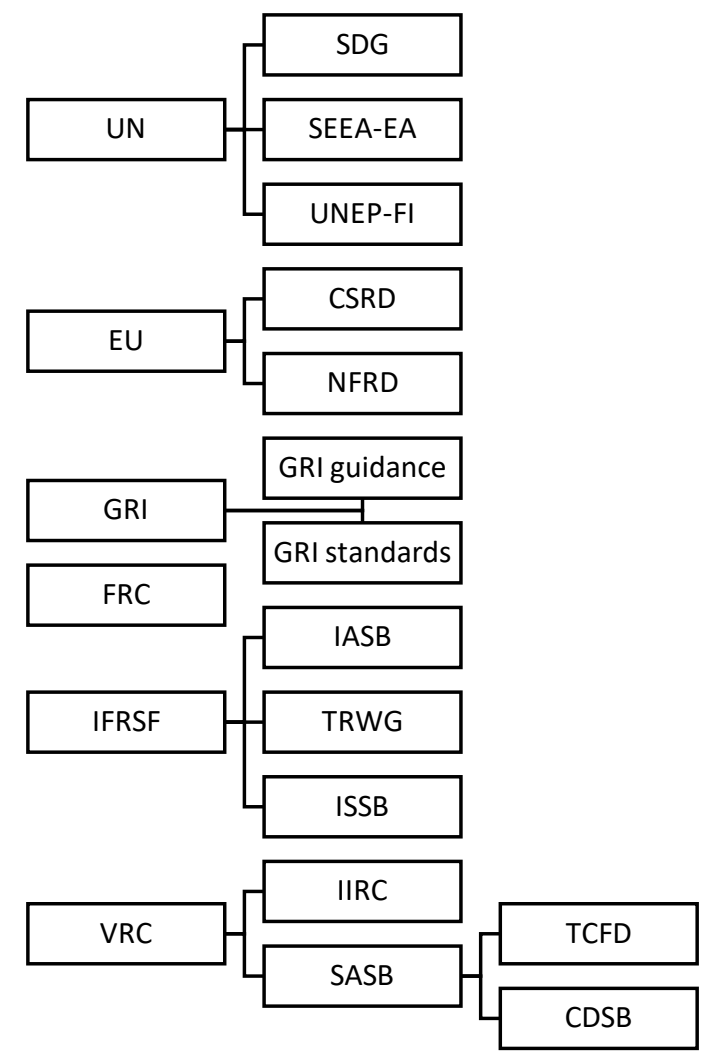

Figure 2: Main players and some key initiatives in the sustainable accounting space (Author, 2022)

\section{Reform challenges}

Notwithstanding rhetoric such as build back better, green economy, net zero, the world seems addicted to fossil fuels. The question is whether, all the green slogans are merely hubris or, in the inimitable works of Greta Thunberg, 'blah blah blah'(Carrington, 2021). Global emissions are NOT decreasing (see Figure 1) so we appear on track for global warming of around $2.4^{\circ} \mathrm{c}$ rather than the 'golden calf' so to speak of $1.5^{\circ} \mathrm{C}$. In fact, the United Nations Environment Programme (2021) indicates that current projections of fossil-fuel use to 2030 are more than double $(110 \%)$ the level needed to prevent a breach of the $1.5^{\circ} \mathrm{c}$ threshold and even exceed by $45 \%$ fossil fuel usage compatible with a $2^{\circ} \mathrm{C}$ temperature rise aspiration. The issue is obviously serious - a fact reinforced by some alarming curiosities. For example, since 1850 over 500 glaciers have disappeared in Switzerland, according to Matthias Huss, a glaciologist at the ETH technical university in Zurich (France 24, 2019). Despite the worrying signals, vested interests, populism, neoliberal ideology and substantive development challenges have, to date, conspired to foil meaningful system reform (Veblen, 1919). Substantive blockages include India and China's coal-based production, misaligned tax systems and debilitating fossil fuel subsidies that COP 26 failed to extirpate, including the $\$ 700$ bn of annual subsidies paid by the 50 largest food producing countries towards very destructive land uses (Goldsmith, 2021). Notwithstanding belated, hubristic claims of the financial sector at COP26 (so called Glasgow Financial Alliance for Net Zero - GFANZ), the challenges remain daunting (Opinion Lex, 2021). Firms need to get beyond 'virtue signalling'. Surely, part of the climate change solution must involve principal-based SAR so that firms systematically record and return independently assured reports on their environmental impacts? 


\section{Methodology}

The research used ablative, reflexive thematic analysis (TA) - a parsimonious approach focused on the research issue but without formal coding (Braun \& Clarke, 2021). Instead, ablation (Latin: ablātǐo) involved an initial scanning of the SAR backdrop to identify key players in the field and generate a tightly focused corpus of their recent SAR documentation. Procedurally, the investigation followed the sequence, illustrated in Figure 3 . First, the research reviewed the SAR backdrop to identify key global players, engaged in the SAR debate or practice. Among the entities fulfilling these criteria were the United Nations (UNEP, UNEP-FI), EU, GRI, SASB and IFRS. From these institutions, the study sourced recent literature (reports, public documents, academic articles, published reports and brochures or web pages) - the SAR corpus. We adopted Maxwell's (2006) pragmatic literature approach isolate papers with a thematic fit (Reisigl \& Wodak, 2009, p. 99). In essence then, the iterative literature review employed a 'tools' rather than 'foundation' metaphor to isolate relevant SAR sources (Maxwell, 2006). We removed marginal narratives from the retained corpus. This left a manageable sample of recently (2021) published SAR texts. The research scanned the corpus, seeking to disentangle its conflicting threads and establish some coherence between opposing narratives. Researcher subjectivity anchored the reflexive TA approach which was a 'situated, interpretative reflexive process' without any coding framework (Braun \& Clarke, 2021, p.333-334). In a 'creative and active process', simplification, questioning and hermeneutic phenomenological reflection generated three initial SAR themes: climate crisis, conservative or radical SAR reform (Braun \& Clarke, 2021; Heidegger, 1927; Husserl, 1928). Subsequently, these initial themes became a lens to critically re-examine the SAR corpus. Further thematic refinement involved immanent critique to establish substantive meaning of underlying narrative structures. It probed beneath the linguistic surface of documents to strip out verbosities and identify contradictions or paradox, only vaguely perceptible at manifest (latent) level. (Braun \& Clarke, 2021; Reisigl et al., 2009; Riessman, 1993; Van Dijk, 1976). After iterative analysis, the research reformulated or refined the themes to dystopic climate crisis fragmentation, conservative single materiality or radical double materiality paradigms. The research synthesised the secondary evidence and concluded that the current accounting system is not fit for purpose and needs to incorporate SAR. The argument over the best approach rumbles on but the research detected some indications that SAR institutional rationalisation and harmonisation is in the offing.

$\Rightarrow \begin{gathered}\text { SAR } \\ \text { SAR } \\ \text { backdrop }\end{gathered} \Rightarrow \begin{aligned} & \text { SAR } \\ & \text { document } \\ & \text { corpus }\end{aligned} \Rightarrow \begin{aligned} & \begin{array}{l}\text { Immanent } \\ \text { critique } \\ \text { - Verbosities } \\ \text { - Contraditions }\end{array} \\ & \text { contions }\end{aligned} \Rightarrow$ SAR themes

Figure 3: The informal ablative reflexive thematic analysis methodology (Author, 2022)

\section{Results}

The results suggest a reformulation of the first SAR theme from climate crisis to fragmented climate crisis dystopia. Refinements to the second and third themes emphasise materiality divergence between conservatives 
with a single materiality investor focus and double materiality perspective tht incorporates wider ecological and social considerations. The IFRS-F-backed ISSB curates the minimalist Anglo-Saxon SAR conservative camp. It consolidates the single materiality SAR paradigm by incorporating VRF, SASB and the IIRC. Radical SAR reformers seek to integrate a range of ecological metrics into financial returns. The global and continental SAR grouping includes the UNDSA, UNEP-FI, EU-C and the GRI. These frameworks or standards cater to broad spectrum of stakeholders and seek to incorporate the impact of firm externalities, including biodiversity and water abstraction and pollution (Laine et al., 2021; Saïd Business School \& Oxford, 2018).

\section{Theme 1: Climate crisis}

Climate change, as it now manifests infectiously or meteorologically and by its prospective implications, is the greatest systemic risk to financial market stability (Pitt-Watson, 2021). Mounting transition, physical and litigation risks effectively preclude the extraction of all identified fossil fuels reserves. As the awareness of climate risks grows, the valuation of entire industries and asset classes is impaired. The risk is systemic, so we need to mitigate. At recent Centre for Accounting Research Education (CARE) conference on 21/09/21, PittWatson acknowledged that the accounting profession has, to put it mildly, dragged its feet for decades on climate risk and is now belatedly scrambling to salvage its diminished credibility. However, Pitt-Wilson advocates for investors or at least has them in his focus. He discretely evaded the key issue dogging financial statements legitimacy - that of an investor-focused single materiality perspective that is unfit for 21st century climate and environmental purpose (Pitt-Watson, 2021).

Ironically, major investors now drive the impetus for SAR change. BlackRock (BR) the world's largest asset manager with $\$ 9$ trillion in assets under management, wants all companies to disclose their transition to netzero plans. Last year, BR voted against 69 companies and against 64 directors for climate-related reasons and put 191 companies on watch. Net zero means asset owners need to eliminate or offset emissions with a combination of low carbon replacements, energy efficiency improvements, and negative emissions and every firm's or public \& third sector entity's business model will be impacted dramatically. Once objectives, barriers, and constraints are recognised, a measurement system should assess agent performance to properly account for key variables in conflicting fields of capital allocation, emissions reductions, and profitability. Accountability requires that agents measure and report the right things that principals then act on. Measurement for measurement's sake, without consequences, is illusory. It is the appearance of accountability but is really noise not signal, or worse, greenwash. For market actors to trust self-reported emissions or other environmental data, it must be collected using agreed objective methodologies AND then independently verified.

Manuel Rodriguez Becerra (2011), the distinguished Columbian environmentalist, is sceptical that we will get beyond the distracting illusion of small-scale forestry projects when big banks are investing billions in extraction activities, including mining, dams, beef etc. (Becerra, 2021). As global banking giants and investment firms vow to divest from polluting energy companies, they are continuing to bankroll another major driver of the climate crisis. Large food and farming corporations are responsible for indirectly, for cutting down vast carbon-storing forests and spewing greenhouse gas emissions into the atmosphere. However, such agricultural investments are largely unnoticed and unchecked. According to Bruno Sarda, a former North America president of CDP, agricultural development represents a potentially catastrophic climate change blind spot. For him, animal protein and dairy are the biggest source of emissions and the new 'oil and gas'.

Feix \& Philippe (2018) analysed institutional CSR narratives and found little mention of divergence between business firms' financial goals and societal interests (aka paradox). In addition, to avoiding discussion the salient paradox of noncongruence between corporate profit objectives and societal needs, these authors found taboos involving multinational firms' continued contribution to global socio-environmental issues and CSR's moderate results in solving these problems. Instead, corporate narratives (spin) depict an antagonism-free and depoliticized world which is essentially marked by unity in destiny, shared values, and common interests. In reality it seems, consumers often confront an unseemly string of privatised monopoly 'organised rip-offs' (N. Cohen, 2017, p.1).

The re-examination of the SAR corpus using critical reflection on the first climate crisis theme reformulated it as dystopic climate crisis fragmentation as the disparate accounting bodies, first, ignored SAR for decades then scrambled to generate a plethora of disparate responses. Now, a tardive consolidation effort under the auspices of IFRS-F is in the offing. 


\section{Theme 2: Conservative approach}

The thrust of the U.K. and U.S.-based accountancy institutions approach to SAR involves, at least initially, single materiality but the FRC is consulting on potentially more robust financial reports and investment labels to reflect direct and indirect environmental impacts and align with EU's SFDR (Financial Conduct Authority, 2021).

\section{FRC}

The FRC is UK's commercial regulator of corporate governance, reporting and audit. In 2019, it noted systemic environmental deficiencies in company governance and reporting. The G7 Impact Taskforce (ITF) notes that the global economic systems must systemically change so that environmental and social factors influence capital allocation to facilitate an inclusive transition towards sustainability (Impact Taskforce, 2021). To date, corporate boards have largely eschewed their environmental responsibilities because of outdated governance frameworks and a tendency to 'tick the box' rather than 'open the can of worms' inherent in true and fair override (TFO)(Garvey et al., 2021, p. 19). Firms need to, urgently, strengthen resilience reporting and update their accounting systems to better reflect direct and indirect environmental impacts (Financial Reporting Council, 2020a). Specifically, the FRC found scope for improvements in Non-Financial Disclosures (NFD) and Greenhouse Gas ( $\underline{G H G}$ ) emissions reporting (Financial Reporting Council, 2020b). Often, NFD were omitted or vague. Only $46 \%$ of companies reviewed credibly articulated the company's climate change impacts but only $29 \%$ described impacts associated with their supply chains. The FRC expects non-financial reporting to address impacts associated with suppliers and customers. Often, the scope and basis of GHG emissions reports is vague and ignores downstream customer lifecycle product usage carbon emissions. But should a car company account for the carbon emitted by drivers of its vehicles? The Financial Conduct Authority's (FCA) encourages companies to use the Task Force on Climate-Related Financial Disclosures (TCFD) and SASB frameworks. From 1 January 2021, FRC insists that UK premium listed companies must provide TCFD disclosures on a 'comply or explain' basis but it is considering expanding reporting requirement to all listed entities (Financial Reporting Council, 2021).

\section{IFRS Foundation (London)}

In 2001, the IFRS Foundation launched as a platform to provide global investors transparent and comparable information. 140 jurisdictions accept the Accounting Standards promulgated by its International Accounting Standards Board (IASB). In 2020, pressure by government and international investors for high quality, transparent, reliable and comparable information on climate and other environmental, social and governance (ESG) matters pushed the Foundation to consult publicly with UK regulatory authorities and government departments. The results suggested a high demand for IFRS sponsored international sustainability reporting standards. The IFRS's credibility, established governance structures and due process, supports the quick rollout of new sustainability standards (Financial Reporting Council, 2020b). On 3 November 2021 at COP26 in Glasgow, the Foundation laughed the International Sustainability Standards Board (ISSB) to develop Sustainability Disclosure Standards ( $\underline{\mathrm{SDS}})$ and sustainability reporting ones. IFRS oversight facilitates connectivity between financial and non-financial reporting. The Foundation's Technical Readiness Working Group (TRWG) has developed a suite of standards for release by 2022. For guidance, the TRWG intends to leverage existing frameworks such as the Sustainability Accounting Standards Board (SASB), Task Force on Climate-Related Financial Disclosures ( $\underline{\text { TCFD }}$ ), Climate Disclosure Standards Board (CDSB). The ISSB intends to consolidate $\underline{\text { SASB }}$ and the International Integrated Reporting Framework (IIRC) into the Value Reporting Foundation (VRF).

However, contentions remain, notably in scoping the standards. A pre-requisite for any sustainability standards is the determination of key stakeholders. The Foundation argues that the ISSB should, at least initially, focus on the information needs of investors. Effectively, for the time being anyway, the Anglo-Saxon accounting setting establishment wants to kick the can of wider stakeholder interests into the long grass. This, albeit pragmatic, scope restriction ensures the ISSB never becomes a purely environmental standards board.

\section{International Sustainability Standards Board ISSB}

The IFRS-F argues for single materiality sustainability so financial statements only disclose sustainability information material to enterprise financial value creation, preservation or erosion. The problem here is that, for large multinationals, the deleterious impacts of many remote corporate activities, although globally immaterial financially may be biologically, culturally or locally highly significant. Even if any inflicted local impacts are negligible at a point in time, cumulatively activities can become noxious (the obvious example here is ubiquitous plastic packaging). The IFRS argues that the alternative, double-materiality approach substantially 
increases standard setting task complexity and diverges from IASB practice. So, the Foundation recommends the ISSB adopt an incremental approach and initially focus on investor-relevant sustainability information. Eventually, the sustainability standards might evolve towards a more comprehensive assessment of the risks and opportunities, entailed by double materiality. Extension to consider EU Non-Financial Reporting Directive (NFRD) would avoid global standards jurisdictional fragmentation but the ISSB will need to set narrative reporting sustainability boundaries. Here, the use of the ESG acronym, although widely used, does present the ISSB with a governance conundrum. In addition to the alignment with other bodies and general conventions, it is important to ensure that the standards are proportionate to stakeholder needs without becoming an onerous regulatory burden.

\section{Value Reporting Foundation (VRF)}

In June 2021, the IIRC merged with the Sustainability Accounting Standards Board (SASB) to form the Value

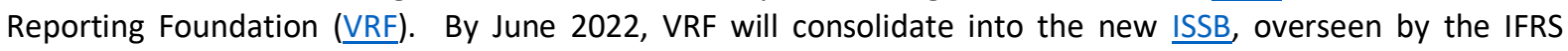
Foundation.

The International Integrated Reporting Council (IIRC)

In 20210, the International Integrated Reporting Committee morphed into the International Integrated Reporting Council (IIRC). It is a global coalition of regulators, investors, companies, standard setters, the accounting profession and NGOs that seeks to enhance accountability and stewardship for financial, manufactured, intellectual, human, social and natural capitals. It supports integrated thinking and balanced decision-making that considers interdependencies between various forms of capital. For example, exclusive focus on financial capital could lead to overemphasis on profit but erode human capital through ill-considered, short-term human resource policies or practices.

Sustainability Accounting Standards Board (SASB). San Francisco

In the United States, the dominant SAR paradigm is market based and involves three related entities (CDSB, $\underline{S A S B}, \underline{T C F D}$ ) that report climate-related risks. A jointly authored report (SASB \& CDSB, 2019, p.iii) notes that effective disclosure of climate-related risks helps mitigate mispricing risk and so stabilizes markets. SASB Standards recognize the need for consistent, comparable, and reliable disclosure of financially-material, decision-useful environmental, social, and governance (ESG) information for investors. The SASB develops and disseminates sustainability accounting standards that help public corporations disclose material, decision-useful information to investors (SASB \& CDSB, 2019). SASB standards are single materiality and industry specific but developed with limited stakeholder engagement. It also curates sector-specific sustainability Key Performance Indicators (KPIs) aligned to the CDSB Framework's principles for reporting environmental information. However, its sustainability focus is restricted to impacts with economic significance for investors.

\section{Task Force on Climate-Related Financial Disclosures (TCFD)}

In 2015, Financial Stability Board (FSB) in the U.S. instigated the Task Force on Climate-Related Financial Disclosures (TCFD) to develop consistent climate-related financial risk information for investors. Cognisant of the climate risk, the U.K. has signalled that it intends to make TCFD-aligned disclosures mandatory by 2025 . The impetus is to avoid asset mispricing and eventual markets instability by effective disclosure of climate-related risks. The TCFD consulted with the $\underline{\text { CDSB }}$ and the SASB and integrated their recommendations into its climate disclosure standards. The UNEP FI'S TCFD programme has incorporated much of TCFD learning into its new climate stress testing guidance.

The conclusion for second conservative SAR reform theme is that Anglo-American institutions and programmes favour a single materiality perspective, focused on the financial interests of investors.

\section{Theme 3: Radical perspectives}

\section{United Nations}

The current global capitalist and conventional financial reporting systems can mask significant firm external impacts (Bebbington \& Unerman, 2018; Busch et al., 2015; Cho, 2021). The United Nations has three initiatives to help temper short-sight commercial proclivities that damage the environment. First, it promulgates Sustainable Development Goals (SDGs) that reflect broad public aspirations for the integrated consideration of environmental, social and economic impacts when assessing development projects such as dams. The $\underline{\text { SDG}}$, 
helped frame the UN's second major sustainability policy lever - accounting system reforms to plug information deficiencies (Jan Bebbington \& Unerman 2018).

The SDGs doubtless helped frame the gestation of the United Nations et al (2021)'s System of Environmental Economic Accounting - Ecosystem Accounting (SEEA-EA) that modernises the current legacy, rather introverted, commercial accounting perspective and helps the profession and their clients recognise their social and environmental responsibilities (United Nations et al., 2021). The proposed dynamic perspective exceeds conventional boundaries of entity-responsibilities and integrates interdisciplinary expertise to capture spatially or temporally dispersed impacts. The SEEA-EA integrates economic, environmental and social data into a single, coherent framework for holistic decision-making and so mitigates the criticism of the IFRS approach raised by e.g. (Cho, 2021).

The United Nations Environment Programme Finance Initiative (UNEP FI) is the third sustainability reform initiative of the international body. As its name suggests, UNEP FI is a global partnership between the United Nations Environment Programme (UNEP) and the financial sector. Over 190 institutions, including banks, insurers and fund managers, work with UNEP to understand the impacts of environmental and social considerations on financial performance. Through its Climate Change Working Group ( $\underline{\mathrm{CCWG}}$ ), it ostensibly promotes greener finance decisions by disseminating the use of non-financial scientific information to supplement market, credit or operational risk assessments. Although the UNEP FI has double materiality pretentions, its focus remains a conventional, single materiality, financial one.

\section{European Union Commission}

Today, many organizations tend to prioritize financial materiality, which is not only detrimental for sustainable development but, ultimately, also to their bottom line. To re-balance priorities, the EU promulgated the Corporate Sustainability Reporting Directive (CSRD), Non-Financial Reporting Directive (NFRD). Along with the GRI Standards and the UN'S SEEA-EA are double materiality stakeholder approaches to SAR (European Commission, 2021; KPMG, 2021). To internalise negative production externalities, firms must be held to account for their impacts. The first step is to have robust governance so that dispersed, deleterious impacts, risks or opportunities are identified and robustly reported. EU law requires certain large companies to disclose information on the way they operate and manage social and environmental challenges. This helps investors, civil society organisations, consumers, policy makers and other stakeholders to evaluate the non-financial performance of large companies and encourages these companies to develop a responsible approach to business. Directive 2014/95/EU Directive 2014/95/EU - also called the Non-Financial Reporting Directive (NFRD) - lays down the rules on disclosure of non-financial and diversity information by certain large companies. This directive amends the Accounting Directive 2013/34/EU.

On 21 April 2021, the European Commission issued their proposed changes to strengthen the nature and extent of sustainability reporting in the EU over the coming years (CSRD). The proposed changes to sustainability reporting are profound and will be fundamental and directly support the European Commission's stated objective of directing investment towards more sustainable activities across the European Union. The CSRD proposals significantly enhance the scope of the existing NFRD rules to cover all large undertakings as well as all those listed on EU regulated markets, except for micro-entities. NFRD has a double materiality perspective acknowledging how financial materiality can differ from social and environmental materiality. Moreover, in contrast to the NFRD, the CRSD sets out in far greater detail the non-financial information that entities should report. As expected, the CSRD introduces mandated EU sustainability standards, to be prepared by the European Financial Reporting Advisory Group (EFRAG) and adopted via secondary legislation. The standards should be based on the recent recommendations recently made by the EFRAG Task Force on Non-Financial Reporting Standards (TFNFRS), with a first set of standards due for adoption by 31 October 2022.

\section{Global Reporting Initiative (GRI)}

Founded in 1997, the GRI (Global Reporting Initiative) is an independent, international non-profit institution, located in Amsterdam with branches in Brazil (2007), China (2009), India (2010), USA (2011), South Africa (2013), Colombia (2014) and Singapore (2019). It promulgates the oldest and most widely adopted sustainability reporting guidelines and standards (GRI, 2021) that enables responsible companies to communicate their significant impacts. In 2000, GRI published its first Guidelines (G1) but regularly updated them (versions G2-G4 by 2013). In 2016, GRI promulgated its first set of standards, predicated on entities identifying (GRI 1) and prioritizing their impacts on the economy, environment, and people. The first standard clarifies critical concepts, explains how to use the Standards and specifies the principles - such as accuracy, balance, and verifiability. 
Entities use a situational analysis to frame their context, identify then assess impacts of routine activities. GRI 2 specifies disclosures in detail for different aspects of an organization's activities. GRI 3 explains step-by step how to identify and assess impacts and their significance and includes a list of material topics. The GRI Standards involve double materiality so that wider social, environmental and economic impacts supplement investor ones as illustrated in Figure 4 below.

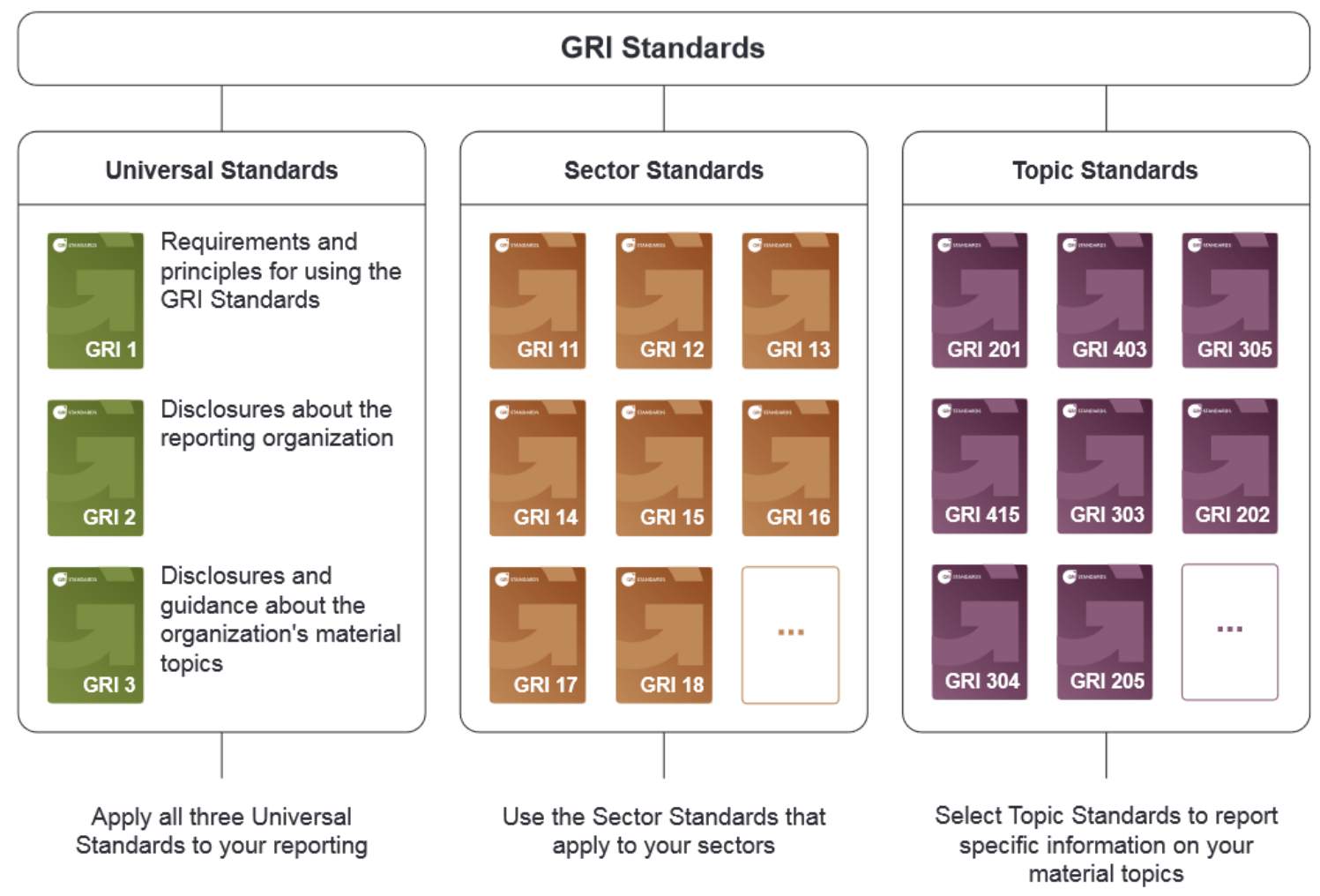

Figure 4: GRI Standards: Universal, Sector and Topic Standards. (GRI, 2020)

The research retained the third theme but refined and extended it to radical double materiality. The three UN initiatives, the European Commission sustainability reporting directives and the GRI standards demonstrate momentum to, finally, rebalance accounting materiality towards integrated sustainable considerations.

\section{Conclusion}

The research used informal ablative, reflexive thematic analysis. It scanned the SAR backdrop to identify the key global players and a corpus of recent relevant literature. An initial scan of the corpus generated three themes involving climate crisis, conservative response or radical SAR approaches. Using these three lenses, the research re-examined the literature, using critical thematic analysis to probe for latent meaning beneath linguistic surface. The re-examination of the first climate crisis theme led to its reformulation as dystopic climate crisis fragmentation in the SAR landscape with a plethora of activity signalling inability or unwillingness of the accounting profession establishment to really face up to their environmental responsibilities. The research validated the opposing conservative or radical theme narratives but enriched them with single materiality or double materiality details.

After two hundred years of unprecedented economic and population growth, capitalism faces its nemesis unless it evolves into a more responsible production mode. Yet global institutions struggle to tackle the problem effectively. Trillions of dollars still flow in the wrong direction, corporate monopolies still rip customers off, fossil fuel extraction continues unabated, carbon dioxide levels inexorably rise, and wider imposts of unseemly corporate activity continue to accumulate in damaged or depleted ecosystems. Trustworthy, integrated, verifiable and comparable accounting information is urgently needed to hold directors to account as a key 
element in the robust policy mix needed to plug missing markets and internalise externalities for healthier, resilient and more equitable futures. In the face of prospective severe climatic-induced disruption or insidious pollution, current accounting and reporting systems seem, frankly, unfit for $21^{\text {st }}$ century purpose.

SAR reforms will involve, first, mandating minimum standards and, shortly afterwards, providing more nonfinancial information to a wider spectrum of stakeholders. Currently, the SAR community seems split into two camps. Conservatives seem to be shuffling the deckchairs on the Titanic so to speak. They may have some legitimate concerns about excessive bureaucratic and regulatory constraints and want to proceed prudently by initially developing standards that reflect enterprise value before extending the SAR remit to social or environmental considerations. Grudgingly, conservative players now recognise that the direction of travel is towards double materiality but advocate for an incremental pathway. The new crime of ecocide may yet concentrate minds and spur reform.

SAR radicals, on the other hand, seek to immediately and explicitly recognise and incorporate non-financial impacts for a broad spectrum of stakeholders into company reports. Double materiality impact indicators could extend to, for example, fossil fuel usage, carbon emissions, plastic content or other pollution externalities. Perhaps, the spate of recent SAR reforms and institutional rationalisations suggest that the fragmented and contested SAR landscape is slowly evolving towards global double materiality harmonisation, underpinned by integrity and inclusive, interoperable data? One can only hope that corporate vested interests are not playing SAR games or what Russians call maskirovka (маскировка) to obfuscate and delay meaningful climate crisis progress while continuing to pocket substantial but private gains, restricted to the privileged current accounting and reporting establishment.

Grammatical note: When italicised, the terms conservative or radical are effectively proper nouns, specific to this study that designate the alternate viewpoints with respect to restricted or broad reform of accounting standards to integrate environmental disclosure. 


\section{Glossary}

IIRC: International integrated Reporting Council

AUM: Assets under management

CARE: centre for Accounting Research Education

CCWG: Climate Change Working Group (UNEP FI)

CDP: is a not-for-profit charity that runs the global disclosure system for investors, companies, cities, states and regions to manage their environmental impacts. https://www.cdp.net/en/companies-discloser

CDSB: Climate Disclosure Standards Board is an international consortium of nine business linked to $\underline{\text { SASB }}$ that promulgates integration of natural with financial capital.

COP26: UN Climate Change Conference (Glasgow, 2021)

CSR: Corporate Sustainable Responsibility

CSRD: Corporate Sustainability Reporting Directive (EU-C)

EFRAG: European Financial Reporting Advisory Group

ESG: Environmental, Social \& Governance

EU-C: European Union Commission

FASB: Financial Accounting Standards Board. The U.S. Securities and Exchange Commission recognises it as the source of GAAP based FA and reporting standards.

FCA: Financial Conduct Authority's (London)

FRC: Financial Reporting Council (London) promotes transparency and integrity in business. It regulates auditors, accountants and actuaries, and sets the UK's Corporate Governance and Stewardship Codes.

FSB: Financial Stability Board a global organization that seeks to promote global financial stability (Basel)

GAAP: Generally Accepted Accounting Principles developed in the US.

GFANZ Glasgow Financial Alliance for Net Zero

GHG: Greenhouse gases (mainly carbon dioxide $\mathrm{CO} 2$ and methane $\mathrm{CH} 4$ )

GRI: Global Reporting Initiative (Amsterdam)

IASB: International Accounting Standards Board (London)

IFRS-F: International Financial Reporting Standards Foundation (London)

IIRC: International Integrated Reporting Council - incorporated under IFRS-F with SASB

IOSCO: International Organisation of Securities Commissions (Madrid) is a worldwide association of national securities regulatory commissions, including the U.S. Securities and Exchange Commission and the U.K. Financial Services Authority (FSA).

ISSB: International Sustainability Standards Board - offshoot of IFRS-F

ITF: Impact Task Force (G7)

IVSC: International Valuation Standards Council

NFD: Non-Financial Disclosure

NFRD: Non-Financial Reporting Directive (EU-C, Brussels)

OECD: Organisation for Economic Cooperation and Development (Paris) 
SAR: Sustainability accounting and reporting

SASB: Sustainability Accounting Standards Board (San Francisco) established in 2011 . It sets standards independently to enhance capital markets efficiency by quality sustainability disclosure for investors. Now consolidated within the VRF

SDG: Sustainable Development Goals promulgated in the UN's (2015) 2030 Agenda for Sustainable Development. 17 SDGs were identified to stimulate critical action (UNEP)

SDR: Sustainability Disclosure Requirements

SDS: Sustainability Disclosure Standards developed by the ISSB

SEEA-EA: UN System of Environmental-Economic Accounting - Ecosystem Accounting, developed and curated by the Statistics Division of the UN's Department of Economic and Social Affairs

SFDR: Sustainability Finance Disclosure Regulation (EU, Brussels)

TCFD: Taskforce on Climate-related Financial Disclosures TCFD, instigated in 2015 by the Basel-based Financial Stability Board $(\underline{F S B})$

TFO: True and Fair Override when accounts depart from accounting standards to disclose material information that reflects a principal based true and fair view.

TFNFRS: Task Force on Non-Financial Reporting Standards (ㅌRAG)

TRWG: Technical Readiness Working Group (IFRS)

UNEP: United Nations Environment Programme

UNEP FI: United Nations Environment Programme Finance Initiative (Geneva) is a global partnership between $\underline{\text { UNEP }}$ and the financial sector, involving 550 institutions that feed into its Climate Change Working Group ( $\underline{\text { CCWG }}$

UNDESA: UN's Department of Economic and Social Affairs that promulgates the SEEA-EA

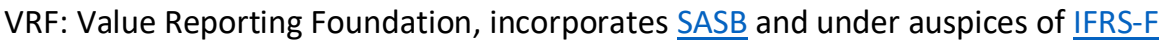




\section{Bibliography}

Bebbington, J., \& Unerman, J. (2018). Achieving the United Nations sustainable development goals. Accounting, Auditing \& Accountability Journal, 31(1), 2-24. https://doi.org/10.1108/AAAJ-05-2017-2929

Becerra, M. R. (2011). Forests and climate change mitigation. Global Business School Network: Race2Imagine Series October 22nd 2021.

Becerra, M. R. (2021). Forests and climate change mitigation. Race2Imagine October 22nd 2021.

Braun, V., \& Clarke, V. (2021). One size fits all? What counts as quality practice in (reflexive) thematic analysis? Qualitative Research in Psychology, 18(3), 328-352. https://doi.org/10.1080/14780887.2020.1769238

Busch, T., Bauer, R., \& Orlitzky, M. (2015). Sustainable development and financial markets: Old paths and new avenues. Business \& Society, 55(3), 303-329. https://doi.org/10.1177/0007650315570701

Carrington, D. (2021, September 28). 'Blah, blah, blah': Greta Thunberg lambasts leaders over climate crisis. The Guardian. https://www.theguardian.com/environment/2021/sep/28/blah-greta-thunberg-leadersclimate-crisis-co2-emissions

Cho, C. (2021). Sustainability (Accounting): The case of ESG and the IFRS,. Egyptian Online Seminars in Business, Accounting and Economics 09/10/2021. https://www.youtube.com/watch?v=PBAE4jfkLr8 (12/10/21).

Church, J. (2021). Climate change scientific update for 2021 CARE conference. Centre for Accounting Research Education Conference 2021: Accounting for Sustainability and Responsible Investing. https://events.climateaction.org/care-conference/dashboard/1/care-conference-1/

Cohen, N. (2017, September 16). The scandal of privatised water is going to blow. The Spectator. https://www.spectator.co.uk/article/the-scandal-of-privatised-water-is-going-to-blow

Cohen, R. (2020). Impact: Reshaping capitalism to drive real change. Ebury Press. https://www.sbs.ox.ac.uk/oxford-answers/reshaping-capitalism-drive-real-change

Coyle, D. (2020). Green recovery must end the reign of GDP, argue Cambridge and UN economists. Bennett Institute for Public Policy. https://www.cam.ac.uk/stories/UNnaturalcapital

Crawford, A., \& Sculthorpe, T. (2021). The plastic Nile. Sky News. https://news.sky.com/video/the-plastic-nile11999381

Dasgupta, P. (2021). Nature: Our most precious asset. https://www.youtube.com/watch?v=JvPJALCZOeo

European Commission. (2021). Corporate sustainability reporting. https://ec.europa.eu/info/businesseconomy-euro/company-reporting-and-auditing/company-reporting/corporate-sustainabilityreporting_en\#standards

Feix, A., \& Philippe, D. (2018). Unpacking the narrative decontestation of CSR: Aspiration for change or defense of the status quo? Business \& Society, 59(1), 129-174. https://doi.org/10.1177/0007650318816434

Financial Conduct Authority. (2021). Sustainability Disclosure Requirements (SDR) and investment labels: Discussion Paper DP21/4.

Financial Reporting Council. (2020a). Climate thematic (Issue November). https://www.frc.org.uk/getattachment/ab63c220-6e2b-47e6-924e-8f369512e0a6/Summary-FINAL.pdf

Financial Reporting Council. (2020b). FRC climate thematic. Reporting - How are companies developing their reporting on climate-related (Issue November). https://www.frc.org.uk/getattachment/6d8c6574-e07f-41a9-b5bb-d3fea57a3ab9/Reporting-FINAL.pdf

Financial Reporting Council. (2021). Frequently asked questions: International sustainability standard setting: factsheet for preparers. https://www.ifrs.org/groups/international-sustainability-standards-board/issbfrequently-asked-questions/ 
France 24. (2019). Swiss to hold high-altitude wake for lost glacier. AFP. https://www.france24.com/en/20190922-swiss-to-hold-high-altitude-wake-for-lost-glacier

Garvey, A. M., Parte, L., McNally, B., \& Gonzalo-Angulo, J. A. (2021). True and fair override: Accounting expert opinions, explanations from behavioural theories, and discussions for sustainability accounting. Sustainability (Switzerland), 13(4), 1-23. https://doi.org/10.3390/su13041928

Goldsmith, R. H. L. (2021, December 31). Radio 4 Today Programme. BBC Radio 4. https://www.bbc.co.uk/sounds/play/m0012svy

GRI. (2020). A short introduction to the GRI Standards. https://www.globalreporting.org/media/wtaf14tw/ashort-introduction-to-the-gri-standards.pdf

GRI. (2021). GRI: Get started with reporting. GRI Standards. https://www.globalreporting.org/how-to-use-thegri-standards/get-started-with-reporting/

Guo, J., Kubli, D., \& Saner, P. (2021). The economics of climate change: no action not an option. In Swiss Re Institute (Issue April). https://www.swissre.com/institute/research/topics-and-risk-dialogues/climateand-natural-catastrophe-risk/expertise-publication-economics-of-climate-change.html

Hamilton, I., \& Rapf, O. (2020). Executive summary of the 2020 global status report for buildings and construction. Global Alliance for Buildings and Construction, 1-7.

Heidegger, M. (1927). Sein und Zeit. Max Niemeyer Verlag.

Husserl, E. (1928). Vorlesungen zur Phänomenologie des inneren Zeitbewusstseins. Max Niemeyer Verlag.

Impact Taskforce. (2021). Time to deliver: mobilising private capital at scale for people and planet. https://www.impact-taskforce.com/media/gq5j445w/time-to-deliver-final.pdf

Ivory, S. B., \& Brooks, S. B. (2018). Managing corporate sustainability with a paradoxical lens: Lessons from strategic agility. Journal of Business Ethics, 148(2), 347-361. https://doi.org/10.1007/s10551-017-3583-6

Jill, A., \& Warren, M. (2020). The Naturalist's Journals of Gilbert White: exploring the roots of accounting for biodiversity and extinction accounting. Accounting, Auditing \& Accountability Journal, 33(8), 1835-1870. https://doi.org/10.1108/AAAJ-03-2016-2450

Kaplan, R. S. (2021). Accounting for climate change: The first rigorous approach to ESG reporting. Egyptian Online Seminars in Business, Accounting and Economics 21/10/2021.

Keynes, J. M. (1930). Treatise on money. Macmillan.

KPMG. (2021). Corporate Sustainability Reporting Directive: What the new CSRD means for you. KPMG Insights. https://home.kpmg/ie/en/home/insights/2021/04/corporate-sustainability-reporting-directive-csrd.html

Laine, M., Tregidga, H., \& Unerman, J. (2021). Sustainability Accounting and Accountability. Routledge. https://doi.org/10.4324/9781003185611

Liikanen, E. (2021). A financial system for net zero. COP26.

Maxwell, J. A. (2006). Literature reviews of, and for, educational research: A commentary on Boote and Beile's "Scholars before researchers." Educational Researcher, 35(9), 28-31. https://doi.org/10.3102/0013189X035009028

Opinion Lex. (2021, November 3). COP26: Carney's $\$ 130$ tn climate pledge is too big to be credible. Financial Times. https://www.ft.com/content/87690ee9-c9b1-44b6-881b-368139560295

Pitt-Watson, J. (2021). Can ESG reporting be consistent with basic accounting principles? Centre for Accounting Research Education Conference 2021: Accounting for Sustainability and Responsible Investing.

Reisigl, M., Wodak, R., \& Meyer, M. (2009). Methods of critical discourse analysis. London: Sage.

Riessman, C. K. (1993). Narrative analysis (Vol. 30). Sage. 
Saïd Business School, \& Oxford, U. of. (2018). SBS responsible business debate: Should corporate sustainability reporting be mandated? https://www.youtube.com/watch?v=lyzkKFgp6NU

SASB, \& CDSB. (2019). Converging on climate risk. https://www.sasb.org/knowledge-hub/converging-onclimate-risk/

Tiwari, K., \& Khan, M. S. (2020). Sustainability accounting and reporting in the industry 4.0. Journal of Cleaner Production, 258, 120783. https://doi.org/https://doi.org/10.1016/j.jclepro.2020.120783

United Nations Environment Programme. (2021). Production Gap Report 2021. https://productiongap.org/2021report/

United Nations et al. (2021). System of environmental economic accounting - Ecosystem accounting. https://seea.un.org/ecosystem-accounting

Van Dijk, T. A. (1976). Narrative macro-structures. PTL: A Journal for Descriptive Poetics and Theory of Literature, 1(1976), 547-568.

Veblen, T. (1919). Vested interests and the common man. B. W. Heubsch. 